\title{
熱線を用いた $\mathrm{CO}_{2}$ 軸対称噴流拡散場の二成分瞬間速度・瞬間濃度の同時計測*
}

\author{
酒井康彦 $* 1$, 長田孝二*2, 久保貴 $* 3$,
} 市野修平 ${ }^{* 4}$, 堀内健二*4

\section{Simultaneous Measurement of Instantaneous Two-Component Velocities and Concentration in an Axisymmetric $\mathrm{CO}_{2}$ Turbulent Jet Diffusion Field by Using Composite Hot-Wire Probe}

\author{
Yasuhiko SAKAI*1, Kouji NAGATA, Takashi KUBO, Shuhei ICHINO and Kenji HORIUCHI \\ ${ }^{* 1}$ Department of Mechanical Science and Engineering, Nagoya University, \\ Furo-cho, Chikusa-ku, Nagoya-shi, Aichi 464-8603 Japan
}

\begin{abstract}
Simultaneous measurements of instantaneous two-component velocities and concentration are conducted in an axisymmetric $\mathrm{CO}_{2}$ turbulent jet diffusion field. Three probes are used. The first is the 'double probe' consisting of two concentration-sensitive I-type hot-wire probes for the simultaneous measurement of instantaneous axial velocity and concentration. The second is the 'Chassaing type' $\mathrm{X}$ hot-wire probe, which is insensitive to local concentration, for measurement of instantaneous two-component velocities in the $\mathrm{CO}_{2}$ diffusion field. The third is the composite probe consisting of the double and Chassaing-type $\mathrm{X}$ probe for simultaneous measurement of instantaneous two-component velocities and concentration. The results show that instantaneous two-component velocities and concentration of $\mathrm{CO}_{2} \mathrm{can}$ be measured by using the present composite probe.
\end{abstract}

Key Words : Jet, Turbulence, Axisymmetric Flow, Turbulent Mixing, Hot-Wire Anemometry

\section{1. 緒言}

気中におけるガスの拡散現象を明らかにすることは, ガス混合装置の設計や大気中での污染物質の拡散予測等 と関連して重要である．また, 気中における局所の瞬時ガス濃度を測定できるセンサーを開発することは, 工業 的に非常に重要である. 熱線あるいは熱膜プローブを用いてガスの瞬間濃度を測定する試みは古くから行われて おり，ヘリウムガスと空気の混合に関しては, Way \& Libby ${ }^{(1)(2)} に$ にって干渉プローブと呼ばれるプローブか提案 された . このプローブは熱膜プローブと熱線プローブで構成され, 加熱された熱膜と熱線を熱的に干渉する程度 まで近接して設置することにより，熱線と熱膜の出力からへリウムガスの瞬間速度と瞬間濃度を決定するもので ある. 兴の後, この干渉プローブは二成分瞬間速度と瞬間濃度の同時測定 ${ }^{(3)}{ }^{(4)}$ にも応用されている.一方, Brown \& Rebollo ${ }^{(5)}$ は熱線と超音速ノズルを組み合わせたプローブ(熱線濃度計)を用いて混合気体の瞬間濃度を測定する 方法を提案している .このプローブと通常の熱線プローブを組み合わせることにより，混合気体の一成分瞬間速 度と瞬間濃度を同時測定する試みもなされている ${ }^{(6)}$. しかし, 熱線濃度計と熱線プローブの干渉を避けるためにプ ローブ同士を $2 \mathrm{~mm}$ 程度離さなければならず(6), 超音速ノズルで構成される熱線濃度計の大きさを考えると, 二成 分速度測定用の X 型プローブとの組み合わせは難しいと思われる .

$\mathrm{CO}_{2}$ ガスと空気の混合に関しては, Chassaing ${ }^{(7)}$ は熱線出力の濃度依存性と加熱比依存性が大きいという特性を 利用して， $\mathrm{CO}_{2}$ ガスの瞬間濃度と一成分瞬間速度の同時測定を行っている.しかしながら，この方法では, 一本

\footnotetext{
* 原稿受付 2010 年 5 月 26 日

*1 正員, フェロー, 名古屋大学大学院工学研究科 (广 464-8603 愛知県名古屋市千種区不老町)

$* 2$ 正員, 名古屋大学大学院工学研究科

*3 正員, 名城大学理工学部 (广 468-8502 愛知県名古屋市天白区塩金口 1-501)

$* 4$ 名古屋大学大学院工学研究科

Email: ysakai@mech.nagoya-u.ac.jp
} 
(a)

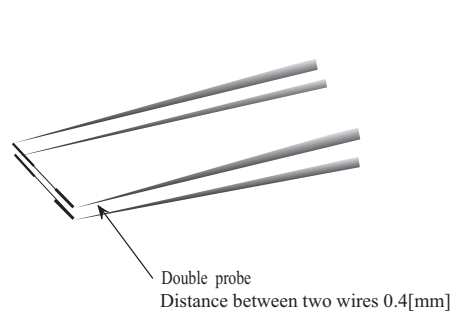

(b)

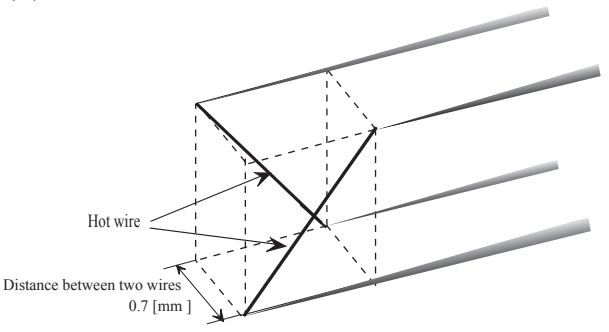

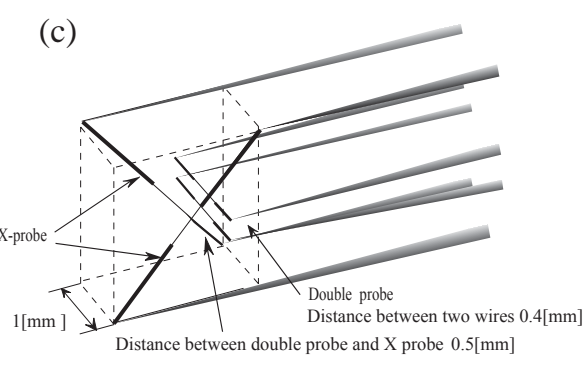

Fig. 1 Schematic of the probes: (a) the 'double probe' for simultaneous measurement of instantaneous axial velocity and $\mathrm{CO}_{2}$ concentration, (b) the Chassaing type $\mathrm{X}$-probe for measurement of instantaneous two-component velocities and (c) the composite probe for simultaneous measurement of instantaneous two-component velocities and $\mathrm{CO}_{2}$ concentration

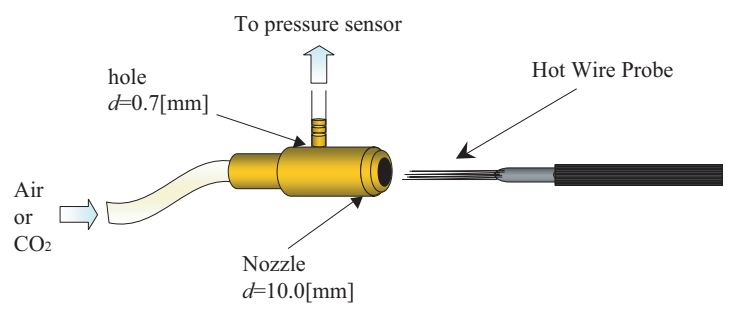

Fig. 2 Calibration nozzle

の熱線の加熱比を濃度感度がなくなるように調整，固定するため，もう一本の熱線の加熱比をどのように設定し ても, 二本熱線プローブとしての濃度感度の向上か望めないという欠点があつた . 兴のため著者ら ${ }^{(8)}$ はさらなる濃 度感度向上のために, 加熱比が大きく異なり，かつどちらも濃度依存性をもつ二本の熱線プローブを用いて，光 れらの出力電圧から速度・濃度への変換方向を考案し, 実際に格子乱流中の $\mathrm{CO}_{2}$ 噴流拡散場を測定し, 弚の有効 性を確かめている．ただし，速度については一成分のみであり，二成分速度測定との組み合わせについては，これ までのところ，弚の試みはなされていない．

乥こで, 本研究では, 熱線法により, 二成分瞬間速度と $\mathrm{CO}_{2}$ ガスの瞬間濃度を同時測定するシステムを開発し， $\mathrm{CO}_{2}$ ガス噴流拡散場で測定を行った . まず, I 型熱線を二本用いることで一成分瞬間速度と瞬間濃度の同時測定を 行った. 次に，加熱比を調節することで濃度感度をなくしたX 型熱線プローブを用いて噴流の速度場を計測した。 最終的には, I 型熱線二本と X 型熱線プローブを組み合わせた複合プローブを作製し，二成分瞬間速度と瞬間濃度 の同時測定を行った. 本報では，これらのプローブを用いた $\mathrm{CO}_{2}$ 噴流拡散場の測定結果について報告する .

\section{2. 熱線による瞬間速度・瞬間濃度の同時測定方法}

\section{$2 \cdot 1$ 各加熱比における熱線出力電圧の濃度依存性}

まず, 一本の I 型熱線プローブについて考える. 谷の場合, 熱線からの出力電圧は, 気種の物性と濃度に依存 する (温度一定の場合) ことが知られている. $\mathrm{CO}_{2}$ と空気の混合気体の場合, 熱線の加熱比 $\varepsilon_{R}=\left(R_{w}-R_{0}\right) / R_{0}($ こ こで, $R_{w}$ : 熱線の抵抗， $R_{0}$ : 常温での熱線の抵抗) を変えることによって出力電圧と濃度の関係を変化させること が可能であり ${ }^{(7)}$, 低加熱の場合には空気流中のほうが $\mathrm{CO}_{2}$ 流中よりも同じ風速に対する出力電圧が高く, 加熱比 が高くなるにつれて兴の大小関係が逆転する ${ }^{(8)}$. また, 加熱比を適度に調節すれば $\mathrm{CO}_{2}$ 濃度に関係なく熱線の出

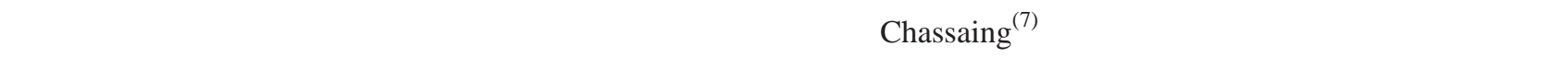
$\mathrm{CO}_{2}$ に対して濃度感度のない加熱比を有する熱線のことを Chassaing 式熱線と呼ぶ．また，Chassaing 式熱線より も高加熱の熱線を高加熱比熱線，Chassaing 式熱線よりも低加熱の熱線を低加熱比熱線と呼ぶこととする . 
(a)

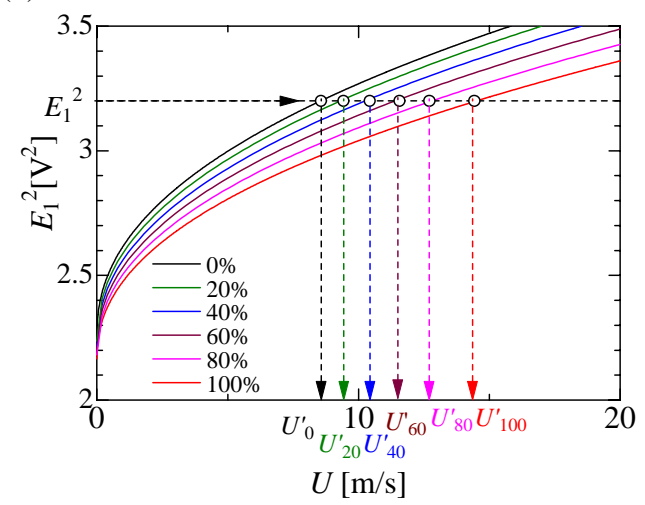

(b)

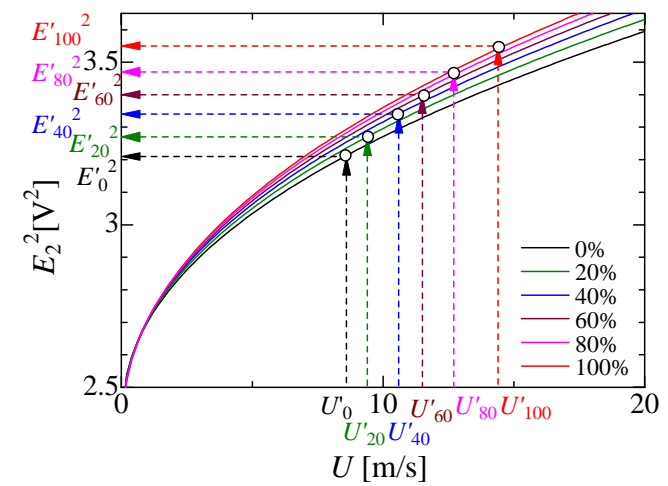

Fig. 3 Calibration of hot-wire probes: (a) for the low overheat-ratio probe and (b) for the high overheat-ratio probe

(a)

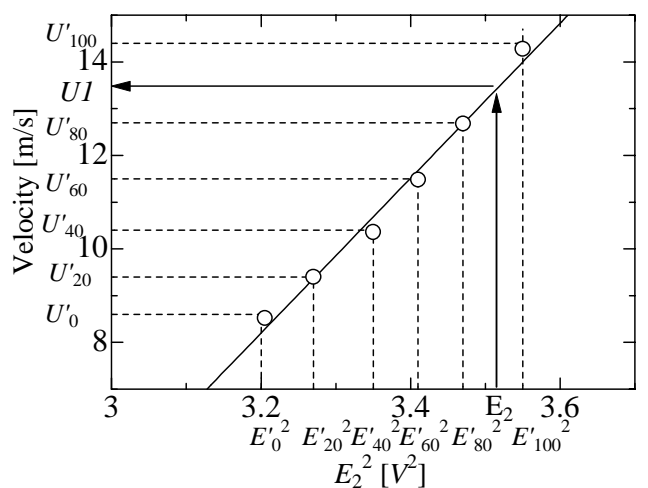

(b)

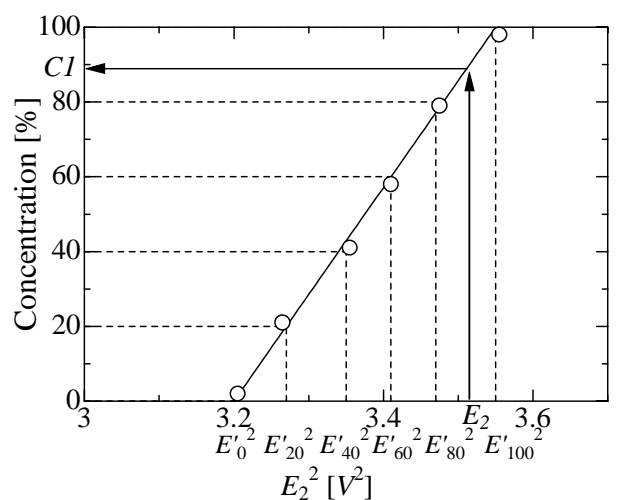

Fig. 4 Determination of (a) instantaneous velocity and (b) instantaneous concentration

\section{$2 \cdot 2$ 二本熱線プローブ}

軸方向瞬間速度と瞬間濃度の同時測定には, 図 1(a) に示す I 型プローブ二本を平行に並べたプローブを用いた . 以降 , このプローブを‘二本熱線プローブ (double probe)’ と呼ぶ. 熱線には銀でコーティングされた白金線 (ウォ ラストン線) を用い, 真鍮製のプロングにはんだ付けした後, 硝酸でエッチング処理を行い, 銀を取り除いて受感 部 (直径 $5 \mu \mathrm{m}$ ，長さ $1 \mathrm{~mm}$ ) とした . 二本の熱線間の距離は互いに干渉しない約 $0.4 \mathrm{~mm}$ とした . 二本の熱線のう ち一方を低加熱比 $\varepsilon_{R}=0.2$, 他方を高加熱比 $\varepsilon_{R}=1.2$ とした .

プローブの較正には図 2 に示すような出口直径が $10 \mathrm{~mm}$ のノズルを使用した . ノズルの側面にはノズル内の静 圧を測定するために直径 $0.7 \mathrm{~mm}$ の穴があけられており，圧力センサーを用いてノズル内の静圧を測定した . ノズ ル内静圧と出口流速の関係をあらかじめ検定しておくことにより，ノズル出口における流速を求めた .プローブ をノズル出口に設置し, ノズル出口流速を徐々に変化させ圧力センサと熱線の出力を同時にサンプリングするこ とにより, 熱線出力と流速の関係が得られる . 熱線からの出力は $\mathrm{CO}_{2}$ 濃度に依存するため , ノズルから噴出させ る空気・ $\mathrm{CO}_{2}$ 混合気の濃度を変えて較正を行い, 各濃度における熱線出力と速度の関係を求めた .

\section{$2 \cdot 3$ 瞬間速度と瞬間濃度の決定方法}

空気および $\mathrm{CO}_{2}$ ガス中での較正曲線が加熱比により逆転する性質を利用して, 以下の方法で速度と濃度を決定 した . 図 3(a), (b) は各々, I 型の低加熱比熱線および高加熱比熱線の出力電圧と速度の関係を $\mathrm{CO}_{2}$ の体積濃度をパ ラメータとして示したものである . 図 3(a) に示すように, まず, 低加熱比熱線の較正曲線と測定した低加熱比熱線 の出力電圧 $E_{1}$ から各 $\mathrm{CO}_{2}$ 濃度に対応する流速 $U_{0}^{\prime}, U_{20}^{\prime}, U_{40}^{\prime}, U_{60}^{\prime}, U_{80}^{\prime}, U_{100}^{\prime}$ を求める .ここで, 下付添字 $(0 \sim 100)$ は $\mathrm{CO}_{2}$ の体積濃度を表す. これらの值と高加熱比熱線の較正曲線を用いて高加熱比熱線の各濃度に対する熱線出 力電圧 $E_{0}^{\prime}, E_{20}^{\prime}, E_{40}^{\prime}, E_{60}^{\prime}, E_{80}^{\prime}, E_{100}^{\prime}$ の値を求める.すると， $E_{0 \sim 100}^{\prime}$ と濃度を仮定したときの速度 $U_{0 \sim 100}^{\prime}$ の関係が得 


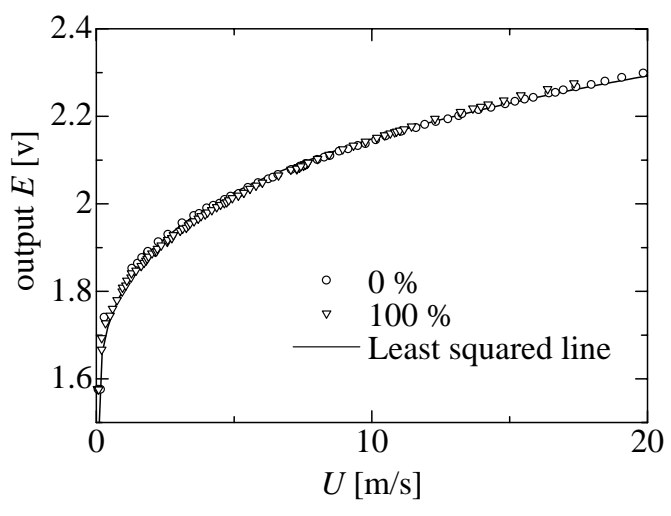

Fig. 5 Calibration curve for Chassaing-type probe

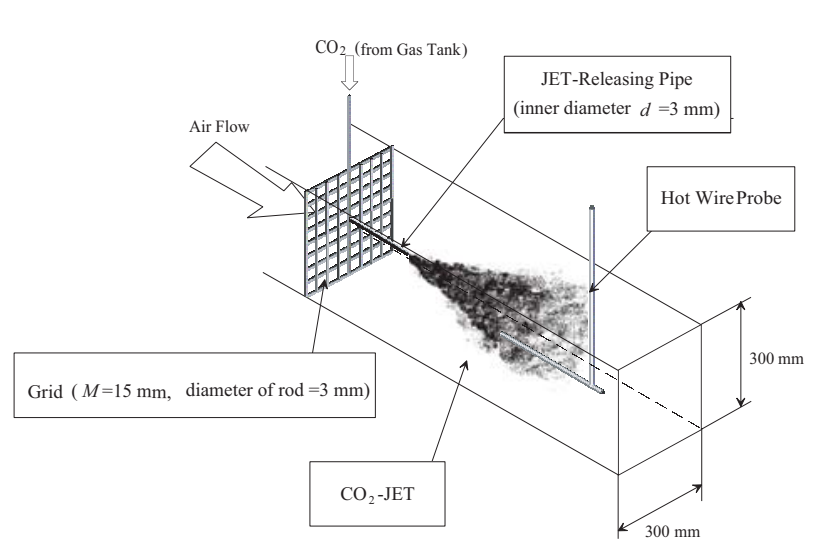

Fig. 6 Schematic of experimental apparatus

られる. 䒓して, 図 4(a), (b)のように, 弚れらの電圧と速度および電圧と濃度の関係を直線近似し, 測定された高 加熱比熱線の出力電圧 $E_{2}$ から瞬間速度 $U_{1}$ および瞬間濃度 $C_{1}$ を決定する . 同じ操作を高加熱比熱線を基準にして 行い, 低加熱比熱線の出力から瞬間速度 $U_{2}$ および瞬間濃度 $C_{2}$ を決定する . 最終的には, $U_{1} と U_{2}, C_{1}$ と $C_{2}$ を光 れ光れ平均して, 瞬間速度 $U$ と瞬間濃度 $C$ を決定する。

\section{$2 \cdot 4$ Chassaing 式熱線プローブによる二成分瞬間速度測定}

加熱比を調節することにより濃度感度をなくしたX 型熱線プローブ (Chassaing 式 X 型熱線プローブ: 図 1(b))を 用いて二成分瞬間速度の測定を行った . 熱線にはタングステン線を用いた . 受感部は直径 $5 \mu \mathrm{m}$, 長さ $1 \mathrm{~mm}$ であ る. 加熱比を $\varepsilon_{R}=0.78$ とした場合の検定曲線を図 5 に示す.較正には前述の較正用ノズルを用いた . 図 5 より， $\mathrm{CO}_{2}$ 濃度に依らず検定曲線が一致することがわかる．

\section{5 四本熱線プローブによる二成分瞬間速度と瞬間濃度の同時測定}

作製した四本熱線プローブ (X-double probe) の概略を図 1(c) に示す .このプローブは濃度測定用の二本熱線プ ローブと速度測定用の Chassaing 式 X 型熱線プローブで構成され, $X$ 型熱線プローブの中心点から $0.5 \mathrm{~mm}$ 後方 (下流側) に二本熱線プローブを配置したものとなっている.プロングには直径 $0.4 \mathrm{~mm}$ のピアノ線を用い, 先端は 鋭利にしてある. 二本熱線プローブ部分の受感部の詳細は前述の通りである. Chassaing 式 X 型熱線プローブ部分 については，二本熱線プローブと組み合わせるためにプローブの間隔が $1 \mathrm{~mm}$ となっている．したがって，Xプ ローブの熱線には受感部 (直径 $5 \mu \mathrm{m}$ ，長さ $1 \mathrm{~mm}$ ) を除いて銅メッキされたタングステン線を用いた . 二本熱線プ ローブの熱線は低加熱比 $\left(\varepsilon_{R}=0.2\right)$ と高加熱比 $\left(\varepsilon_{R}=1.2\right)$ に $X$ 型熱線プローブの熱線の加熱比は濃度感度がな なる $\varepsilon_{R}=0.78$ に設定した . X 型熱線プローブと二本熱線プローブによって得られる測定値の間にはわずかな時間 遅れが存在するが，この遅れ時間は Taylor の凍結仮説を用いて時系列をずらすことで補正した．

\section{3. 実験装置および実験条件}

\section{$3 \cdot 1$ 実験装置}

実験装置 (テストセクション) の概略を図 6 に示す . 風洞は吹出し型であり, 送風機, ディフューザ, 整流部, 縮 流胴，テストセクション，および排気部で構成される . 縮流胴出口の寸法は $0.31 \mathrm{~m} \times 0.31 \mathrm{~m}$ であり，縮流胴で発 生した境界層を排除するために, 縮流胴とテストセクションの間には $5 \mathrm{~mm}$ の隙間が存在する . したがって , テス トセクションの断面は $0.3 \mathrm{~m} \times 0.3 \mathrm{~m}$ である. テストセクション入口から $0.2 \mathrm{~m}$ の位置に乱流格子を設置した . 乱 流格子を構成する棒 (円柱) の直径は $3 \mathrm{~mm}$, 格子間隔は $M=15 \mathrm{~mm}$ である. 乱流格子の閉塞率は 0.36 である. 格 子面の中央を通る格子棒の一本を格子棒と外径が同一の中空のパイプとし, 流れ方向に長さ $15 \mathrm{~cm} の \mathrm{CO}_{2}$ 噴出用 パイプ (内径 $d=3 \mathrm{~mm}$, 外径 $3.2 \mathrm{~mm}$ ) を設けた . 座標系は $\mathrm{CO}_{2}$ 噴出用パイプ出口中心を原点とし, 下流方向に $x$, 


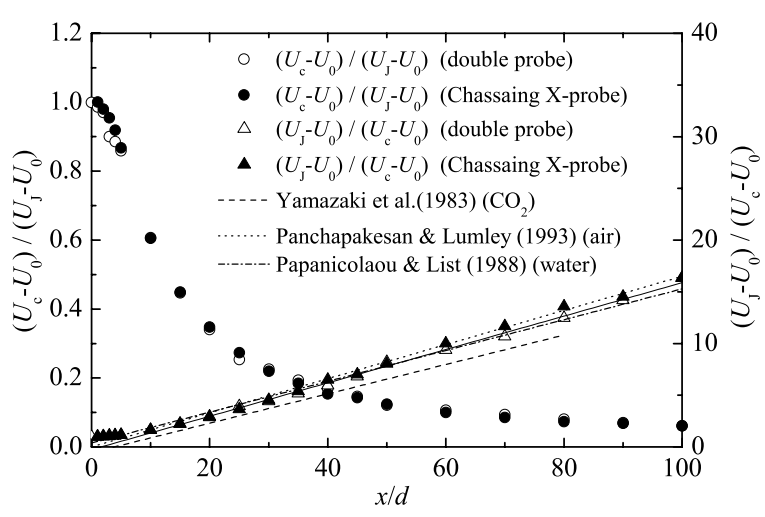

(a) Axial velocity

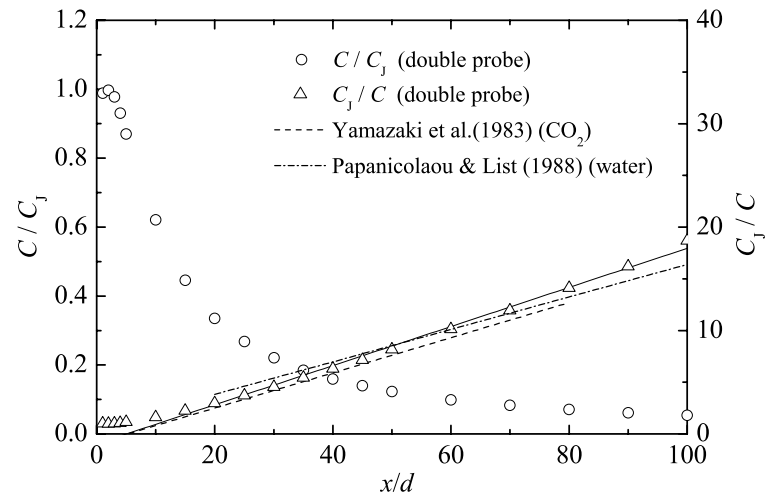

(b) Concentration

Fig. 7 Axial variations of mean values

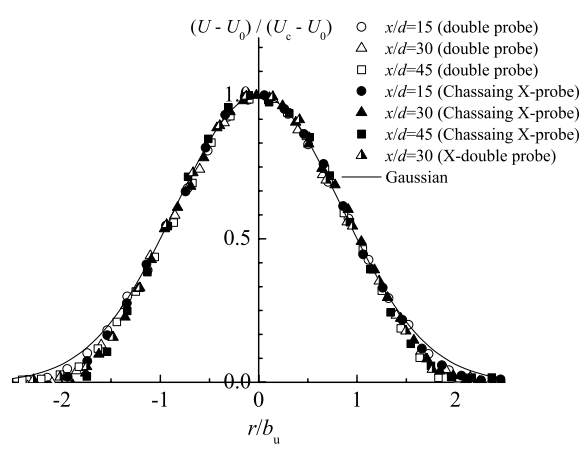

(a) Axial velocity

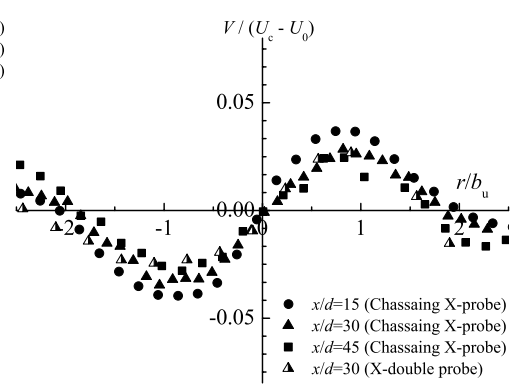

(b) Radial velocity

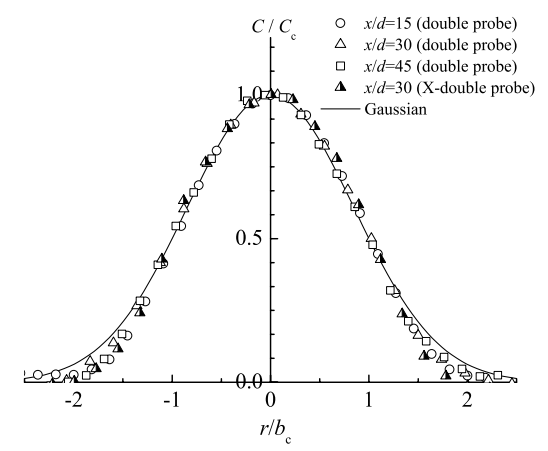

(c) Concentration

Fig. 8 Radial variations of mean values

半径方向に $r$ とした .

\section{$3 \cdot 2$ 実験条件}

本研究では, $\mathrm{CO}_{2}$ ガスがテストセクション内に蓄積するのを防ぐために周囲流 (主流) を設けた . 主流の流速 を $U_{0}=6.0 \mathrm{~m} / \mathrm{s}, \mathrm{CO}_{2}$ ガスの噴流出口速度を $U_{J}=19.0 \mathrm{~m} / \mathrm{s}$ とした .このとき, 噴流出口速度 $U_{J}$ の主流に対する 相対速度を用いた噴流レイノルズ数は $R e_{J}=\left(U_{J}-U_{0}\right) d / v_{C O_{2}}=5,000$, 格子間隔に基づく主流のレイノルズ数は

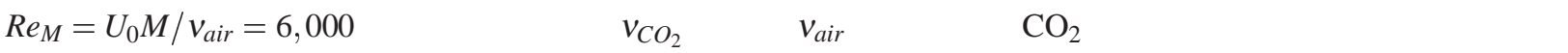

測定は中心軸上 $(r=0)$ および噴流出口下流の三断面 $(x / d=15,30,45)$ で行われた . ただし，四本熱線プローブ による測定は $x / d=30$ の断面でのみ行われた . サンプリング周波数を $10 \mathrm{kHz}$ ，サンプリング点数を 262,144 (約 26 秒)とした .

\section{4. 結果および考察}

\section{1 平均值}

軸上平均流速 $U_{c}$ の中心軸上変化を図 7(a) に示す. 横軸は噴流出口直径 $d$ で無次元化された下流方向距離 $x / d$ を, 縦軸は軸上平均速度 $U_{c}$ の主流に対する相対速度 $\left(U_{c}-U_{0}\right)$ を噴出速度 $U_{J}$ の主流に対する相対速度 $\left(U_{J}-U_{0}\right)$ て無 次元化した值, およびその逆数を示している. 図 7(a)より, 二本熱線プローブと Chassaing 式 X 型熱線プローブに よる測定值が良好に一致することが確認できる . なお, 分布が直線となる $x / d=10$ 以降において最小二乗近似し た場合の傾き (図中の実線) は 0.161 であった . 参考として , 山崎ら ${ }^{(9)}$ にる $\mathrm{CO}_{2}$ 噴流の測定結果 $\left(R e_{J}=18,100\right)$, Panchapakesan \& Lumley ${ }^{(10)}$ による空気噴流の測定結果 $\left(R e_{J}=11,000\right)$ および Papanicolaou \& List ${ }^{(11)}$ による水中噴 流の測定結果 $\left(R e_{J}=11,000\right)$ も図中にプロットした .ただし， $U_{c}$ の中心軸上変化は噴出ガス密度に依存する ${ }^{(9)} の$ 


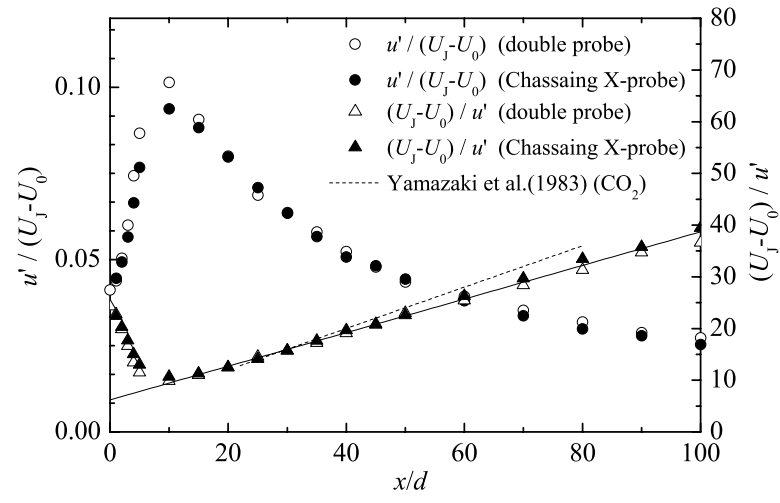

(a) Axial velocity

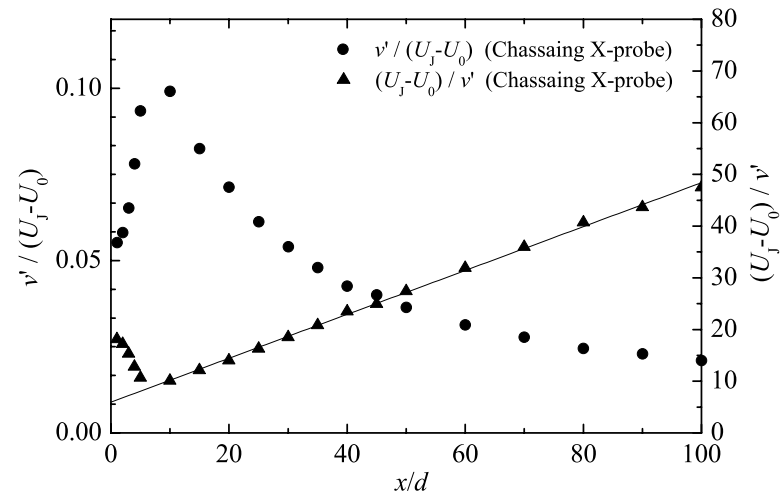

(b) Radial velocity

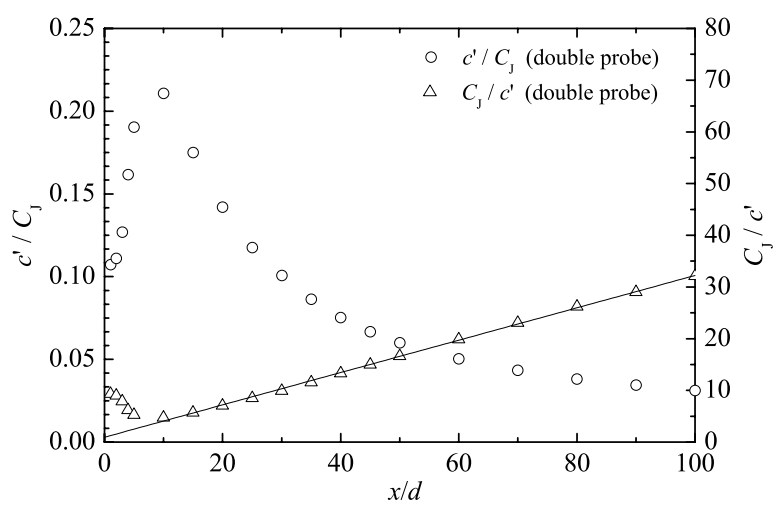

(c) Concentration

Fig. 9 Axial variations of rms values

で注意が必要である.本実験で用いた $\mathrm{CO}_{2}$ の場合，空気に対する比重はおよ光 1.53 である .

平均濃度 $C$ の中心軸上変化を図 7(b) に示す . 縦軸は噴流出口濃度 $C_{J}$ て無次元化された平均濃度および午の逆数

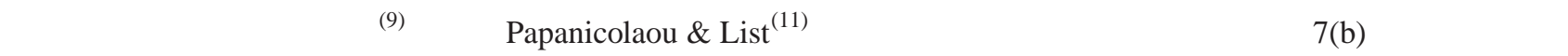
度の逆数の分布も下流方向に直線的に増加することか確認できる. 分布が直線となる $x / d=10$ 以降において最小 二乗近似した場合の傾き (図中の実線) は 0.189 であった .なお, $C$ の中心軸上変化も噴出ガス密度に依存するこ とが報告されている(9)

軸方向平均流速 $U$, 半径方向平均流速 $V$ および平均濃度 $C$ の半径方向変化を図 8 に示す.縦軸は中心軸上にお ける平均相対速度あるいは平均濃度で無次元化された平均流速および平均濃度であり, 横軸は光れ光れの断面に おける軸方向平均流速あるいは平均濃度の半值幅 (光れ光れ $b_{u}, b_{c}$ ) で無次元化された半径方向距離である. $U$ およ びCに関しては, 経験的近似曲線として知られる Gauss 分布によく一致し, 各断面とも相似な分布となった . 一 方， $V$ は原点を中心とした点対称の分布となり，噴流出口に近い $x / d=15$ で下流の $x / d=30 や 45$ よりも大きな 值をもつ傾向が見られた . なお，いずれの分布においても，異なるプローブを用いた測定結果はほぼ一致してお り，測定が精度よく行われていることが確認できる。

\section{$4 \cdot 2 \mathrm{rms}$ 值}

軸方向および半径方向速度変動の rms 值の下流方向変化を図 9(a), (b) に光れ光れ示す. 縦軸は相対速度 $\left(U_{J}-U_{0}\right)$

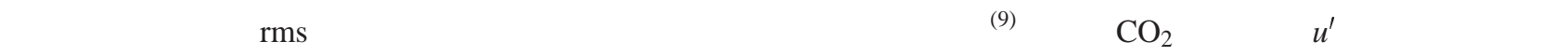
中にプロットした (山崎らの実験では, 鉛直方向 $\mathrm{rms}$ 速度 $v^{\prime}$ と $\mathrm{rms}$ 濃度 $c^{\prime}$ の測定は行われていない) . $u^{\prime}$ の逆数は 下流方向に直線的に増加し, Chassaing 式 X 型熱線プローブによる測定結果ともよく一致した . 分布が直線となる $x / d=10$ 以降において最小二乗近似した場合の傾き (図中の実線) は 0.325 であった . ただし, 速度変動 $\mathrm{rms}$ 值の

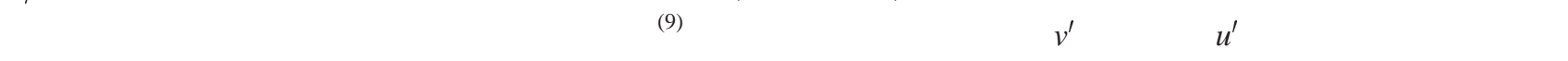




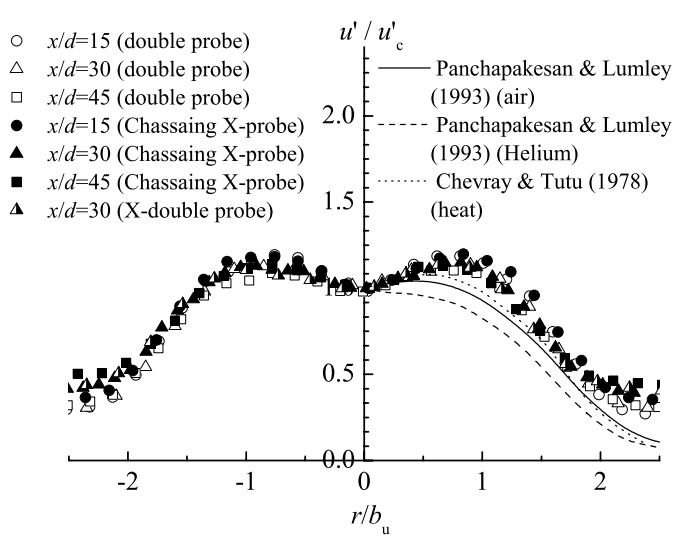

(a) Axial velocity

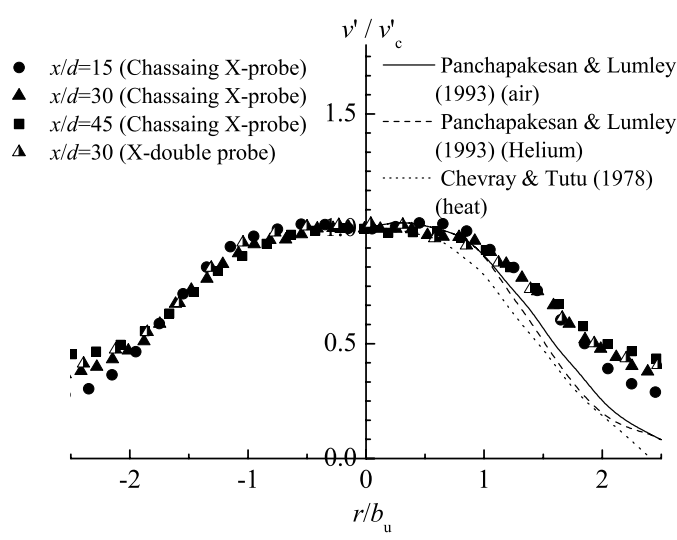

(b) Radial velocity

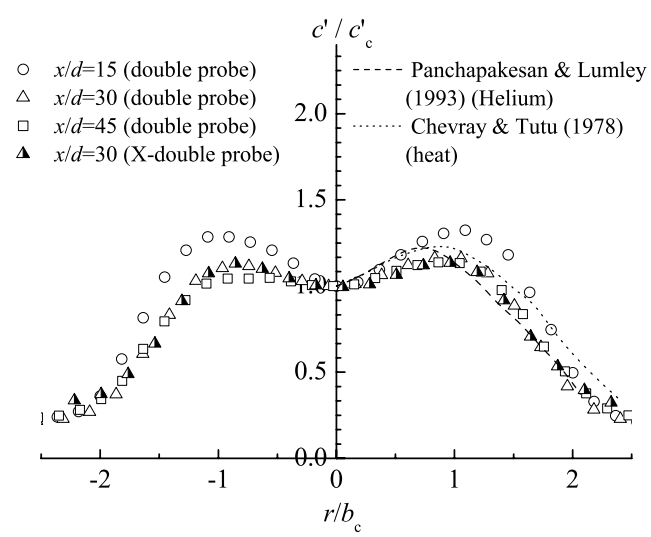

(c) Concentration

Fig. 10 Radial variations of rms values

向を示した . rms 濃度 $c^{\prime}$ の下流方向変化を図 9(c) に示す. 縦軸は噴流出口濃度 $C_{J}$ で無次元化された $\mathrm{rms}$ 濃度 $c^{\prime}$, および光の逆数である. $c^{\prime}$ の逆数は下流方向に直線的に増加し, 分布が直線となる $x / d=10$ 以降において最小二 乗近似した場合の傾き (図中の実線) は 0.312 であった .

$\mathrm{rms}$ 速度 $u^{\prime}, v^{\prime}$ ，および $\mathrm{rms}$ 濃度 $c^{\prime}$ の半径方向変化を図 $4 \cdot 1$ に示す. 縦軸は中心軸上における弚れ光れの值 $u_{c}^{\prime}$, $v_{c}^{\prime}, c_{c}^{\prime}$ で無次元化されている.横軸は図 8 と同樣である . 図 $4 \cdot 1$ より，いずれの分布においても，異なるプローブ を用いて測定された結果はほぼ一致しており，変動値の測定も精度よく行われていることか確認できる . 図 4·1(a) より，政は中心軸からやや離れた場所でピークをもち，測定した三断面ともほぼ相似な形状であった . また， $u^{\prime}$ は 他の研究者による測定值 ${ }^{(4)}{ }^{(10)(12)}$ と比べてやや大きな値となったが, 噴出ガス密度等の実験条件が異なるために定 量的に比較することはできない，一方， $v^{\prime}$ (図 4-1(b)) は, $u^{\prime}$ の分布とは異なり，明確なピークを持たない分布となっ た . 測定した三断面でほぼ相似な形状となることは $u^{\prime}$ の場合と同樣である . なお，本研究では周囲流か格子乱流 なので, 噴流外縁部でも格子乱流の乱れのために, 速度の rms 值は零とならない . 図 4·1(c) より, $c^{\prime}$ に関しては $u^{\prime}$ と同樣に中心軸からやや離れた場所でピークをもち,$x / d=30$ 以降で相似な分布となった . 実験条件が異なるた め定量的な比較はできないが, 本研究で得られた $c^{\prime}$ の分布傾向は, 他の研究者による測定值 ${ }^{(4)}{ }^{(12)}$ と同樣であった .

\section{$4 \cdot 3$ レイノルズ応力}

レイノルズ応力 $<u v>$ の半径方向変化を図 11 に示す . 縦軸の $<u v>$ は, 中心軸上における変動の $\mathrm{rms}$ 值で無 次元化されている．横軸は図 8 と同樣である . 参考として Panchapakesan \& Lumley ${ }^{(10)}$ による結果もプロットした . レイノルズ応力の分布は原点に対して点対称な分布となり， $x / d=30$ 以降で相似な分布となった . また, Chassaing 式 X 型熱線プローブと四本熱線プローブによる測定結果はほぼ一致しており，レイノルズ応力の測定が精度よく 行われていることが確認できる . 


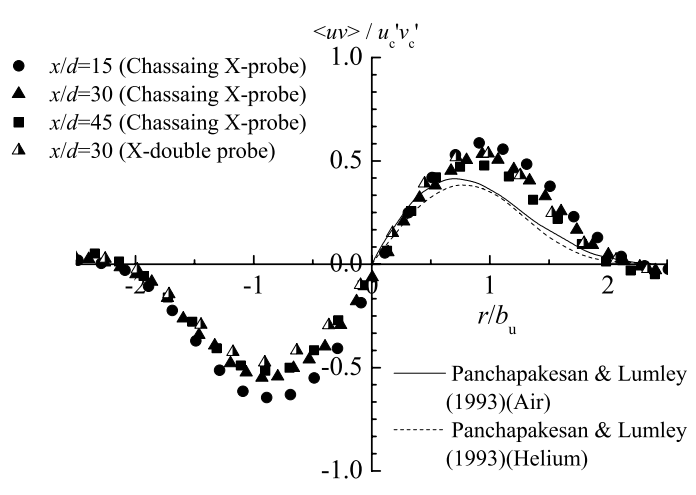

Fig. 11 Radial variation of Reynolds stress

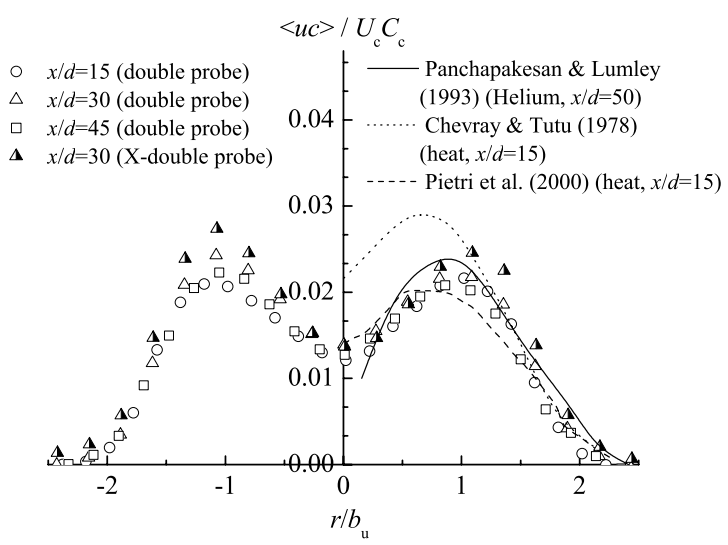

(a) Axial turbulent mass flux

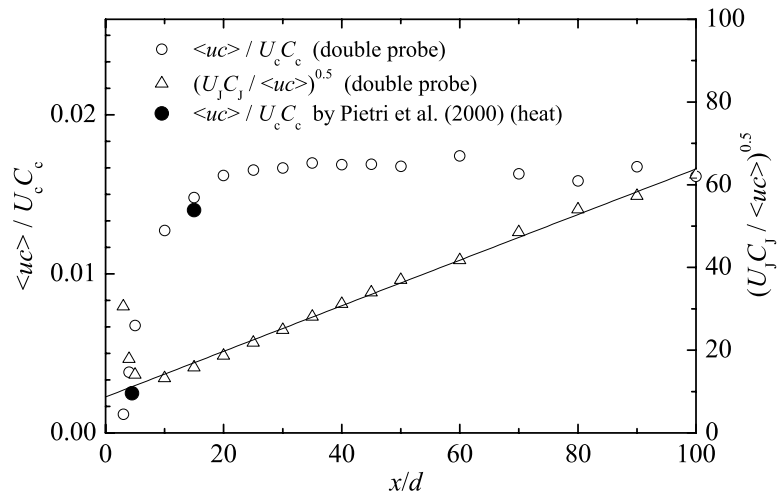

Fig. 12 Axial variation of axial turbulent mass flux

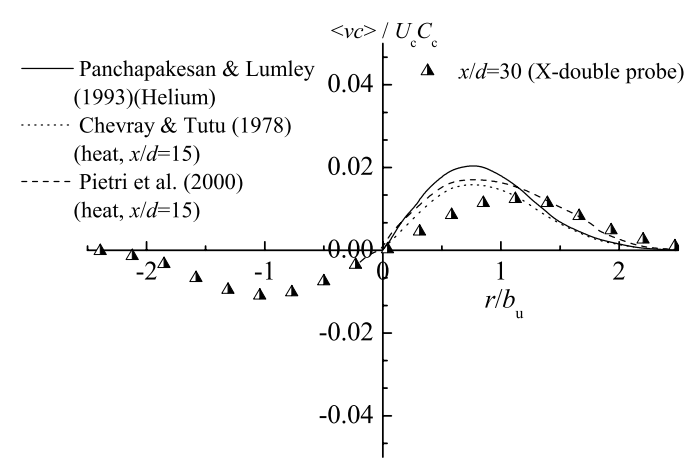

(b) Radial turbulent mass flux

Fig. 13 Radial variations of turbulent mass flux

\section{$4 \cdot 4$ 乱流物質フラックス}

軸方向乱流物質フラックス $<u c>$ の中心軸上変化を図 12 に示す. 縦軸の $<u c>$ は中心軸上の軸方向平均流速 と平均濃度の積 $U_{c} C_{c}$ で無次元化されている．また，こう配拡散の概念が成立する際に $x / d$ に比例することが予測 される $\sqrt{U_{J} C_{J} /<u c>}$ の分布もあわせて示す. 図 12 より, $x / d=10$ 以降では $\sqrt{U_{J} C_{J} /<u c>}$ は直線分布を示す ことがわかる．なお，中心軸上では常に< $\langle c>=0$ である .

軸方向乱流物質フラックス $<u c>$ および半径方向乱流物質フラックス $<v c>$ の半径方向分布を図 13 に示す． 縦軸の無次元化は図 12 と同樣である. 図 13 中には, Panchapakesan \& Lumley ${ }^{(4)}$ によるへリウムガスの乱流物質フ ラックス, Chevar \& Tutu ${ }^{(12)}$, Pietri et al. ${ }^{(13)}$ による乱流熱フラックスの測定值も参考としてプロットしている $.<u c>$ に関しては, 測定値にばらつきが大きいものの, 相似に近い分布が得られた . また, 弚の分布傾向は, 他の研究 者による測定值 ${ }^{(4)(12)(13)}$ と同樣である.一方，〈vc>は原点に対して点対称な分布となった . また, 他の研究者に よる測定値 ${ }^{(4)}{ }^{(12)(13)}$ と同樣の分布傾向を示した . なお, 乱流フラックスの分布は噴出ガス密度やレイノルズ数に依 存するため，既往データと定量的な比較をすることはできない．

\section{5 結合確率密度関数}

結合確率密度関数は乱流中でのスカラーの混合現象を明らかにするうえで, また , 乱流のモデリングの観点か らも非常に重要な乱流統計量の一つである ${ }^{(13)} \cdot x / d=30$ の $r / b_{u}=0,0.54,1.08,1.35$ において測定された半径方向 速度変動 $v$ と濃度変動 $c$ の結合確率密度関数を図 14 に示す.縦軸と横軸の変動は光れぞれの rms 值で無次元化さ れている $v$ と $c$ は中心軸上においては相関をもたないが(図 14(a)), 中心軸から外縁部に向かうに従い, 正の相 関をもつようになることが確認できる．また, 中心軸から離れるに従い間欠性が強くなるため, ピークが負の速 


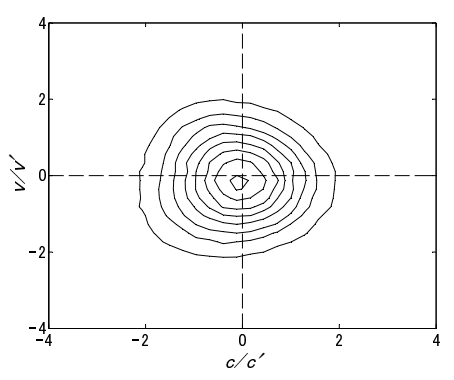

(a) $r / b_{u}=0$

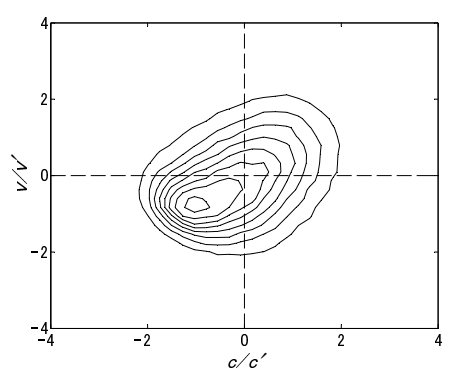

(c) $r / b_{u}=1.08$

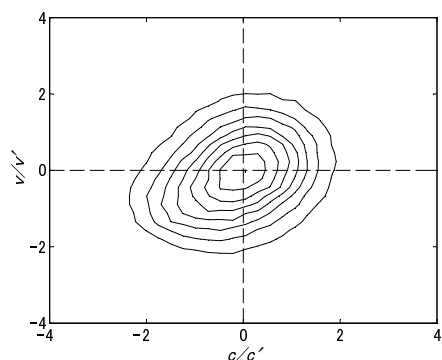

(b) $r / b_{u}=0.54$

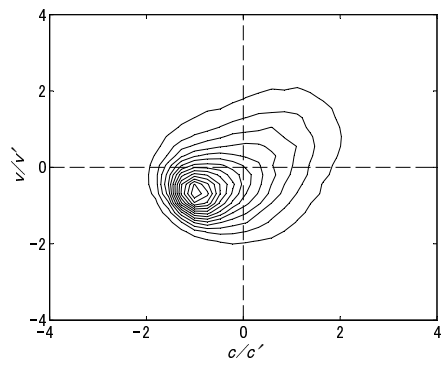

(d) $r / b_{u}=1.35$

Fig. 14 Joint PDF of $v$ and $c$

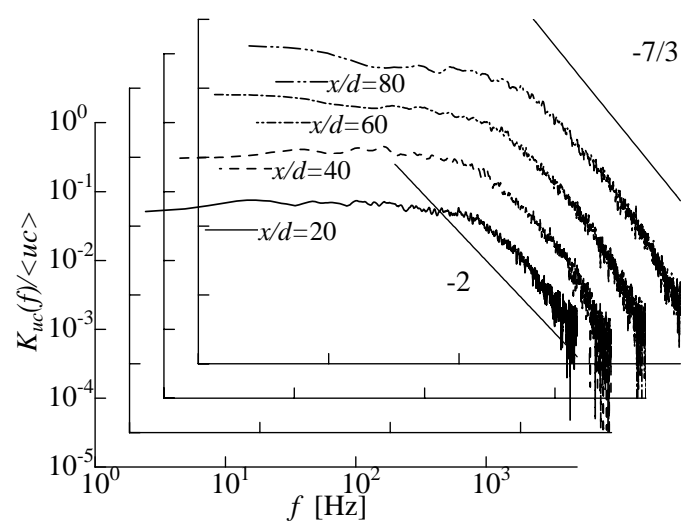

Fig. 15 Axial variations of cospectra of $u$ and $c$

度変動・負の濃度変動の領域に移っていき, 兴の值も大きくなることがわかる．

$4 \cdot 6$ コスペクトル

中心軸上における軸方向速度変動 $u$ と濃度变動 $c$ のコスペクトル $K_{u c}$ の分布を図 15 に示す. 横軸は周波数 $f$ $(\mathrm{Hz})$, 縦軸は軸方向乱流物質フラックス<uc>で無次元化されたコスペクトルを示す . 図 15 より，噴流の上流部 ではコスペクトルは-2 乗に近い傾きを示し，下流では-7/3 乗に近い傾きを示すことがわかる . ただし，図を省略 するが, 上流部では $u$ と $c$ のパワースペクトルに- $5 / 3$ 乗を示す領域か現れなかったので, 本実験結果からコスペク トルのベき乗則を議論する際には注意が必要である .

\section{5. 結 言}

本研究では, I 型熱線二本と Chassaing 式 X 型熱線プローブを組み合わせた複合プローブを作製し, $\mathrm{CO}_{2}$ ガス噴 流拡散場で二成分瞬間速度と瞬間濃度の同時測定を行った. 平均值や変動 $\mathrm{rms}$ 值 , レイノルズ応力, 乱流物質フ ラックス, 結合確率密度関数等を評価した結果, 二成分瞬間速度と瞬間濃度が十分な精度で測定できていること 
が確認された . 今後, 本測定法が噴流拡散場のみならず, 樣々な拡散場に対して応用されることが期待される .

$$
\text { 謝 辞 }
$$

本研究は, 科研費 (22360076 および 22360077) および独立行政法人日本学術振興会と英国 RS との二国間交流事 業 (共同研究) による支援を得て行われた .

$$
\text { 文献 }
$$

(1) Way, J. \& Libby, P. A., "Hot-Wire Probes for Measuring Velocity and Concentration in Helium-Air Mixtures", AIAA Journal, Vol.8, No.5 (1970), pp.976-978.

(2) Way, J. \& Libby, P. A., "Application of Hot-Wire Anemometry and Digital Techniques to Measurements in a Turbulent Helium Jet”, AIAA Journal, Vol.9, No.8 (1971), pp.1567-1573.

(3) Stanford, R. A. \& Libby, P. A., "Further Applications of Hot-Wire Anemometry to Turbulence Measurements in Helium-Air Mixtures", The Physics of Fluids, Vol.17, No.7 (1974), pp.1353-1361.

(4) Panchapakesan, N. R. \& Lumley, J. L., "Turbulence Measurements in Axisymmetric Jet of Air and Helium. Part 2. Helium Jet", Journal of Fluid Mechanics, Vol.246 (1993), pp.225-247.

(5) Brown, G. L. \& Rebollo, M. R., "A Small, Fast-Response Probe to Measure Composition of a Binary Gas Mixture”, AIAA Journal, Vol.10, No.5 (1972), pp.649-652.

(6) 江良嘉信, “熱線利用による気体の濃度・速度の同時測定 (第 1 報, 測定原理)”, 日本機械学会論文集 $B$ 編, Vol.56, No.528 (1990), pp.2358-2363.

(7) Chassaing, P., "Heat Transfer from Cylindrical Anemometer Probes in $\mathrm{CO}_{2}$-Air Mixtures", The Physics of Fluids, Vol.20, No.8 (1977), pp.1260-1262.

(8) Sakai, Y., Watanabe, T., Kamohara, S., Kushida, T. \& Nakamura, I., "Simultaneous Measurements of Concentration and Velocity in a $\mathrm{CO}_{2}$ Jet Issuing into a Grid Turbulence by Two-Sensor Hot-Wire Probe”, International Journal of Heat and Fluid Flow, Vol. 22 (2001), pp. 227-236.

（9）山崎正和, 平沢信三, 城戶伸夫, 大屋正明 \& 永田勝也, “乱流自由噴流の拡散過程における密度の効果”, 日本機械学会論文集 $B$ 編, Vol.49, No.446 (1983), pp.2043-2052.

(10) Panchapakesan, N. R. \& Lumley, J. L., "Turbulence Measurements in Axisymmetric Jet of Air and Helium. Part 2. Air Jet”, Journal of Fluid Mechanics, Vol.246 (1993), pp.197-223.

(11) Papanicolaou, P. N. \& List, E. J., "Investigation of Round Vertical Turbulent Buoyant Jet”, Journal of Fluid Mechanics, Vol.195 (1988), pp.341-391.

(12) Chevray, R. \& Tutu, N. K., "Intermittency and Preferential Transport of Heat in a Round Jet", Journal of Fluid Mechanics, Vol.88 (1978), pp.133-160.

(13) Pietri, L., Amielh, M. \& Anselmet F., "Simultaneous Measurements of Temperature and Velocity Fluctuations in a Slightly Heated Jet Combining a Cold Wire and Laser Doppler Anemometry", International Journal of Heat and Fluid Flow, Vol.21 (2000), pp.22-36. 